PERM JOURNAL OF PETROLEUM AND MINING ENGINEERING

ВЕСТНИК ПНИПУ. ГЕОЛОГИЯ. НЕФТЕТАЗОВОЕ И ГОРНОЕ ДЕЛО

ISSN 2224-9923

Volume/Toм 18 №1, 2018

http://vestnik,pstu.ru/geo/

УДК 622.276:553.982.044

Article / Статья

(C) PNRPU / ПНИПУ, 2018

\title{
THE JUSTIFICATION OF ZONAL OIL AND GAS POTENTIAL OF THE TERRITORY OF VISIMSKAYA MONOCLINE BY GEOCHEMICAL CRITERIA
}

\section{Vladislav I. Galkin, Konstantin A. Koshkin ${ }^{1}$, Oleg A. Melkishev}

Perm National Research Polytechnic University (29 Komsomolskiy av., Perm, 614990, Russian Federation)

${ }^{1}$ Uraloil LLC (4 Sibirskaya st., Perm, 614990, Russian Federation)

\section{ОБОСНОВАНИЕ ЗОНАЛЬНОЙ НЕФТЕГАЗОНОСНОСТИ ТЕРРИТОРИИ ВИСИМСКОЙ МОНОКЛИНАЛИ ПО ГЕОХИМИЧЕСКИМ КРИТЕРИЯМ}

\section{В.И. Галкин, К.А. Кошкин ${ }^{1}$, О.А. Мелкишев}

Пермский национальный исследовательский политехнический университет (614990, Россия, г. Пермь, Комсомольский пр., 29) ${ }^{1} \mathrm{OOO} \mathrm{«УралОйл»} \mathrm{(614990,} \mathrm{Россия,} \mathrm{г.} \mathrm{Пермь,} \mathrm{ул.} \mathrm{Сибирская,} \mathrm{4)}$

Received / Получена: 22.05.2018. Accepted / Принята: 24.08.2018. Published / Опубликована: 28.09.2018

\section{Key words:}

probability, linear statistical model, multidimensional statistical model, correlation coefficient, oil and gas potential, statistical criteria, geochemical and bitumen characteristics, organic matter, geochemistry.

\begin{abstract}
The paper presents the zonal probability and statistical assessment of the generation potential of deposits that form oil and gas potential of the territory of Visimskaya monocline. Databases on geochemical and bituminological characteristics of dispersed organic matter (DOM) in Domanicoid type deposits of the Upper Devonian-Tournaisian formation were used. The following indicators were used: content of organic carbon $\mathrm{S}_{\text {org }}, \%$; organic matter OM, \%; composition of DOM (content of bitumoids: \% - chloroform - CBE, petroleum - PB, alcohol-benzene - ABB, humic acids - HumA, \%, insoluble residue - IR, \%) and characteristics of DOM conversion (ratio of chloroform bitumen to alcohol-benzene one $-\mathrm{CBE} / \mathrm{ABB}$, bitumoid coefficient $-\beta$ ), as well as the conversion factor for $\mathrm{S}_{\text {org }}-\mathrm{K}_{\mathrm{c}}$. In order to determine the informativeness of these characteristics, the Student's $(t)$ and Pearson's $\left(\chi^{2}\right)$ statistical criteria were used. When building models for predicting the zonal oil and gas potential of the territory of Visimskaya monocline, one-dimensional and step-by-step multidimensional regression analyzes were used, which allowed to construct one-dimensional and multidimensional regression linear models. Using the step-by-step multidimensional regression analysis a complex criterion was developed taking into account influence of each geochemical indicator separately and their combinations.

This made it possible to construct a scheme for distribution of probability of petroleum potential of the territory of Visimskaya monocline. Analysis of the scheme showed that the most favorable geochemical conditions for the formation of petroleum potential due to DOM are observed in the central part of Visimskaya monocline (within the Maykorskoye field and surrounding area, bounded by the likelihood more than 0.5). Besides, areas in the south of Visimskaya monocline in the territories where $P_{\text {comp }}^{\mathrm{rx}}>0.5$ are of particular interes in terms of zonal oil and gas potential. North of Visimskaya monocline probably has a certain interest as well.
\end{abstract}

В статье выполняется зональная вероятностно-статистическая оценка генерационного потенциала отложений, формирующих нефтегазоносность территории Висимской моноклинали. Использованы базы данных по геохимическим и битуминологическим характеристикам рассеянного органического вещества (РОВ) в отложениях доманикоидного типа верхнедевонско-турнейской толщи. Были использованы следующие показатели: содержание органического углерода $C_{\text {орг }} \%$; органического вещества ОВ, \%; состав РОВ (содержание битумоидов, \%: - хлороформенных - Б спиртобензольных - Бсб, гуминовых кислот - ГумК, нерастворимого остатка - НО, \%) и характеристики преобразования РОВ (отношение концентраций хлороформенного битумоида к спиртобензольному $-Б_{\mathrm{x} л} / Б_{c \sigma}$, битумоидный коэффициент $-\beta$ ), a также коэффициент пересчета для $C_{\text {орг }}-K_{k}$. Для определения информативности этих характеристик использованы статистические критерии Стьюдента $(t)$ и Пирсона $\left(\chi^{2}\right)$. При построении моделей прогноза зональной нефтегазоносности территории Висимской моноклинали использовались одномерный и пошаговый многомерный регрессионный анализы, что позволило построить одномерные и многомерные регрессионные линейные модели. С помощью пошагового многомерного регрессионного анализа разработан комплексный критерий, учитывающий влияние как каждого геохимического показателя в отдельности, так и их сочетаний.

Это позволило построить схему распределения вероятности нефтегазоносности для территории Висимской моноклинали, анализ которой показал, что максимально благоприятные геохимические условия формирования нефтегазоносности за счет РОВ наблюдаются в центральной части Висимской моноклинали (в пределах Майкорского месторождения и территории вокруг него, ограниченной изовероятностью больше 0,5). Также определенный интерес с точки зрения зональной нефтегазоносности представляют участки на юге Висимской моноклинали на территориях, где $P_{\text {комा }}^{\text {гx }}>0,5$. Вероятно, определенный интерес имеют территории и на севере Висимской моноклинали.

\footnotetext{
Vladislav I. Galkin (Author ID in Scopus: 55418067700 ) - Doctor of Geology and Mineralogy, Professor, Head of the Department of Oil and Gas Geology (tel.: +007 3422198017, e-mail: vgalkin@pstu.ru).

Konstantin A. Koshkin - Head of the Department for Geology and Licensing (tel.: + 00734223568 81, e-mail: konstkoshkin@rambler.ru). The contact person for correspondence. Oleg A. Melkishev - PhD in Engineering, Associate Professor at the Department of Oil and Gas Geology (tel.: +007 342 219 84 11, e-mail: melkishev@pstu.ru).

Галкин Владислав Игнатьевич - доктор геолого-минералогических наук, профессор, заведующий кафедрой геологии нефти и газа (тел.: +007 3422198017 , e-mail: vgalkin@pstu.ru). Кошкин Константин Александрович - начальник отдела геологии и лицензирования (тел.: +007342 235 68 81, e-mail: konstkoshkin@rambler.ru). Кoнтактное лицо для переписки. Мелкишев Олег Александрович - кандидат технических наук, доцент кафедры геологии нефти и газа (тел.: +007 342 219 84 11, e-mail: melkishev@pstu.ru).
} 


\section{Introduction}

Conventional methods for estimating oil and gas potential do not always allow identifying those local objects that could contain oil accumulations. Many authors propose the use different quantitative or qualitative criteria for zonal prediction of oil and gas content.

The paper presents the zonal probability and statistical assessment of the generation potential of deposits that form oil and gas potential of the territory of Visimskaya monocline. As for entire Perm region, there are conventional oil and gas source formations presented by sediments of the Upper Devonian-Tournaissian carbonate $\left(D_{3}-C_{1} t\right)$ complex [1-12].

In order to overcome this challenge, we used databases on geochemical and bituminological characteristics of dispersed organic matter (DOM) of the Upper Devonian-Tournaisian carbonate sediments determined in wells in the Visimskaya monocline.

The following indicators were used: the content of organic compounds in the rock (organic carbon $C_{\text {org }}, \%$, and organic matter OM, \%); DOM composition (bitumoid content, \% - chloroform $\mathrm{B}_{\mathrm{CBE}}$, petroleum $-\mathrm{B}_{\mathrm{PB}}$, alcohol-benzene $-\mathrm{B}_{\mathrm{ABB}}$, humic acids - HumA, insoluble residue - IR) and characteristics of DOM conversion (ratio of chloroform bitumen to alcohol-benzene one $\mathrm{B}_{\mathrm{CBE}} / \mathrm{B}_{\mathrm{ABB}}$, bitumoid coefficient $-\beta$ as well as the conversion factor for $\mathrm{S}_{\mathrm{org}}-\mathrm{K}_{\mathrm{c}}$.

Statistical analysis was performed according to 325 core tests on geochemical characteristics.

Oil and gas source formation In the UpperDevonian-Tournaisian oil and gas complex are of the Domanicoid type, which are currently associated with the formation of the main volume of oil and gas deposits in the entire sedimentary cover of the northeastern Volga-Ural oil and gas province, which includes the Visimskaya monocline. Earlier, various authors reviewed the geochemical features of each stratigraphic unit of these sediments, revealed their generating role, and carried out studies on the prediction of oil and gas content. Geological and geochemical features of these deposits were studied by the authors in sufficient detail for the entire territory of the Perm region [1-8]. It should be noted here that in works mentioned little attention has been paid to the peculiarities of the distribution of DOM over the territory of the Visimskaya monocline. This is largely due to the fact that there are currently few oil and gas fields discovered in this area, while in a rather limited stratigraphic range. According to the authors of this article, the use of mathematical methods will allow to assess the relationship between the characteristics of DOM and the oil and gas potential of the territory of the Visimskaya monocline.

Methods to build geological and mathematical models for solving various problems are given in [13-38]. Elements of mathematical statistics and probability theory were used in constructing onedimensional and multidimensional linear statistical models. Those elements are described in detail in the works of both domestic and foreign authors $[1,11,20,27,29,30,39-46]$.

\section{Construction of one-dimensional models}

Results of studies of samples from wells located within the boundaries of the Visimskaya monocline and near by are analized. Initially, indicators characterizing DOM on the studied deposits were conventionally divided into two groups. The first group includes tests on DOM for wells located near the fields and directly in their contours. The second one includes tests from wells located outside the oil fields.

The first statistical tool for estimating the degree of difference of parameters for two samples is to test hypotheses about differences or nondifferences between the mean values of DOM characteristics under consideration using Student's $t$-test:

$$
t_{p}=\frac{\left|X_{1}-X_{2}\right|}{\sqrt{\frac{1}{n_{1}}+\frac{1}{n_{2}}\left(\frac{\left(n_{1}-1\right) S_{1}^{2}+\left(n_{2}-1\right) S_{2}^{2}}{n_{1}+n_{2}-2}\right)}},
$$

where $X_{1}, X_{2}$ - average values of DOM for oil and "empty" areas respectively; $S_{1}^{2}, S_{2}^{2}$ - dispersion of indicators. Differences in mean values are considered statistically significant if $t_{p}>t_{t}$. The $t_{t}$ values are determined depending on the amount of compared data and the level of significance $(\alpha=0.05)$.

The data of statistical calculations of average values $(t$-criterion and attained significance level $p$ ) of geochemical and bitumen parameters in groups for deposits of the Domanic type of Upper- 
Devonian-Tournaisian deposits $\left(\mathrm{D}_{3}-\mathrm{C}_{1}\right)$ are given in Table 1.

The statistical significance of differences in the average values of geochemical and bitumen characteristics of the DOM of the Upper Devonian-Tournaisian sequence was established for three indicators: $\mathrm{K}_{\mathrm{c}}, \mathrm{B}_{\mathrm{ABB}}, \mathrm{B}_{\mathrm{CBE}}$. The maximum statistical difference by criterion $t$ is obtained for $\mathrm{B}_{\mathrm{CBE}}$, minimal - OM. In order to assess the possibility of the formation of the petroleum potential of the Visimskaya monocline according to the DOM characteristics of the Upper DevonianTournaisian formation, individual forecast models were constructed for them to assess the petroleum potential. The method of constructing such models is described in sufficient detail in work [1]. Consider the construction of individual probabilistic models.

Table 1

Comparison of average values of geochemical and bituminous characteristics and individual probabilistic models of oil and gas for deposits of domanic type $\mathrm{D}_{3}-\mathrm{C}_{1}$

\begin{tabular}{|c|c|c|c|c|}
\hline \multirow[b]{2}{*}{ Indicator } & \multicolumn{2}{|c|}{ Statistical characteristics of indicators } & \multirow{2}{*}{$\begin{array}{l}\text { Student's } \\
\text { criterion } \frac{t}{p}\end{array}$} & \multirow{2}{*}{$\begin{array}{l}\text { Top line - the equation of probability of belonging } \\
\text { to a class of territories within the contours of } \\
\text { deposits; medium line - scope of the model; lower } \\
\text { line - range of probability change }\end{array}$} \\
\hline & $\begin{array}{l}\text { territory of contours of } \\
\text { deposits (group 1) }\end{array}$ & $\begin{array}{l}\text { territory beyond the } \\
\text { contours of deposits } \\
\text { (group 2) }\end{array}$ & & \\
\hline \multicolumn{5}{|c|}{ (in the contour $n=95$, beyond the contour $n=142$ ) } \\
\hline $\mathrm{IR}, \%$ & $\frac{47.4 \pm 42.4}{0.501 \pm 0.002}$ & $\frac{53.5 \pm 42.0}{0.499 \pm 0.001}$ & $\frac{-1.21853}{0.22424}$ & $\begin{array}{c}P(\mathrm{IR})=0.502-0.0005 \mathrm{IR} \\
0.35-99.75 \% \\
0.497-0.502\end{array}$ \\
\hline$C_{\text {org }}, \%$ & $\frac{0.64 \pm 1.23}{0.501 \pm 0.003}$ & $\frac{0.44 \pm 0.62}{0.499 \pm 0.002}$ & $\underline{0.61471}$ & $\begin{array}{c}P\left(C_{\text {org }}\right)=0.499+0.00425 C_{\text {org }} \\
0.02-24.33 \% \\
0.499-0.602\end{array}$ \\
\hline $\mathrm{OM}, \%$ & $\frac{0.81 \pm 1.54}{0.501 \pm 0.003}$ & $\frac{0.57 \pm 0.86}{0.499 \pm 0.003}$ & $\underline{0.54493}$ & $\begin{array}{c}P(\mathrm{OM})=0.499+0.00321 \mathrm{OM} \\
0.03-32.36 \% \\
0.499-0.603 \\
\end{array}$ \\
\hline $\mathrm{B}_{\mathrm{PB}}, \%$ & $\frac{0.006 \pm 0.018}{0.511 \pm 0.072}$ & $\frac{0.0003 \pm 0.01}{0.489 \pm 0.072}$ & $\frac{3.49030}{0.00054}$ & $\begin{array}{c}P\left(\mathrm{~B}_{\mathrm{PB}}\right)=0.488+3.9047 \mathrm{~B}_{\mathrm{PB}} \\
0.000-0.08 \% \\
0.488-0.800\end{array}$ \\
\hline $\mathrm{B}_{\mathrm{CBE}}, \%$ & $\frac{0.056 \pm 0.258}{0.504 \pm 0.038}$ & $\frac{0.021 \pm 0.030}{0.496 \pm 0.004}$ & $\frac{1.61845}{0.10690}$ & $\begin{aligned} P\left(\mathrm{~B}_{\mathrm{CBE}}\right)= & 0.495+0.15082 \mathrm{~B}_{\mathrm{CBE}} \\
& 0.000-2.5 \% \\
& 0.495-0.872\end{aligned}$ \\
\hline $\mathrm{B}_{\mathrm{ABB}}, \%$ & $\frac{0.064 \pm 0.086}{0.504 \pm 0.021}$ & $\frac{0.033 \pm 0.011}{0.497 \pm 0.010}$ & $\frac{3.65523}{0.00031}$ & $\begin{array}{c}P\left(\mathrm{~B}_{\mathrm{ABB}}\right)=0.488+0.24752 \mathrm{~B}_{\mathrm{ABB}} \\
0.000-0.940 \% \\
0.489-0.723\end{array}$ \\
\hline HumA, \% & $\frac{0.003 \pm 0.010}{0.500 \pm 0.005}$ & $\frac{0.004 \pm 0.057}{0.500 \pm 0.006}$ & $\frac{-0.77114}{0.48314}$ & $\begin{array}{c}P(\text { HumA })=0.501-0.4559 \text { HumA } \\
0.00-0.08 \% \\
0.464-0.501\end{array}$ \\
\hline $\begin{array}{l}\mathrm{B}_{\mathrm{CBE}} / \mathrm{B}_{\mathrm{ABB}} \text {, rel. } \\
\text { units }\end{array}$ & $\frac{1.63 \pm 3.54}{0.503 \pm 0.020}$ & $\frac{0.78 \pm 1.39}{0.498 \pm 0.008}$ & $\frac{1.76051}{0.07962}$ & $\begin{aligned} P\left(\mathrm{~B}_{\mathrm{CBE}} / \mathrm{B}_{\mathrm{ABB}}\right)= & 0.495+0.00572 \mathrm{~B}_{\mathrm{CBE}} / \mathrm{B}_{\mathrm{ABB}} \\
& 0.00-20.8 \% \\
& 0.495-0.613\end{aligned}$ \\
\hline$\beta, \%$ & $\frac{10.47 \pm 14.54}{0.501 \pm 0.001}$ & $\frac{7.21 \pm 14.82}{0.499 \pm 0.010}$ & $\frac{0.62548}{0.53226}$ & $\begin{array}{c}P(\beta)=0.496+0.0092 \beta \\
0.05-88.88 \% \\
0.496-0.577 \\
\end{array}$ \\
\hline $\mathrm{K}_{\mathrm{c}}$, rel. units & $\frac{1.27 \pm 0.04}{0.516 \pm 0.085}$ & $\frac{1.29 \pm 0.041}{0.483 \pm 0.090}$ & $\frac{2.87379}{0.00581}$ & $\begin{array}{c}P\left(\mathrm{~K}_{\mathrm{c}}\right)=3.399-2.259 \mathrm{~K}_{\mathrm{c}} \\
1.25-1.33 \text { rel. units } \\
0.394-0.575 \\
\end{array}$ \\
\hline
\end{tabular}

Note: * - in the numerator - average values of the indicator and standard deviation in the class, in the denominator - the average value of the probability and standard deviation in the class.

Table 2

Distribution of $\mathrm{B}_{\mathrm{CBE}} / \mathrm{B}_{\mathrm{ABB}}$ values on Domanic type deposits

\begin{tabular}{|l|c|c|c|c|c|c|c|c|c|c|}
\hline \multicolumn{1}{|c|}{ Feature class } & \multicolumn{7}{|c|}{ Variation interval $\mathrm{B}_{\mathrm{CBE}} / \mathrm{B}_{\mathrm{ABB}}$, rel. units } \\
\cline { 2 - 11 } & $0.0-2.0$ & $2.0-4.0$ & $4.0-6.0$ & $6.0-8.0$ & $8.0-10.0$ & $10.0-12.0$ & $12.0-14.0$ & $14.0-16.0$ & More 16.0 \\
\hline $\begin{array}{l}\text { Territories within the contours } \\
\text { of deposits }(n=95)\end{array}$ & 0.886 & - & 0.031 & 0.010 & - & 0.010 & 0.021 & 0.021 & 0.021 \\
\hline $\begin{array}{l}\text { Territories outside the contours } \\
\text { of deposits }(n=142)\end{array}$ & 0.922 & 0.036 & 0.021 & 0.007 & 0.007 & 0.007 & - & - & - \\
\hline
\end{tabular}


As an example, let's perform a statistical analysis on the $\mathrm{B}_{\mathrm{CBE}} / \mathrm{B}_{\mathrm{ABB}}$ indicator for samples taken within the contours of deposits and beyond. Comparison of the average values given in Table 1 shows that the average value for territories within the contours of the deposits is 1.634, for the territories beyond the contours of the deposit 0.782 . According to the criterion $t$, the mean values are not different, since $p=0.07962$.

Distribution of $\mathrm{B}_{\mathrm{CBE}} / \mathrm{B}_{\mathrm{ABB}}$ values over the Domanic deposits is given in Table 2.

That shows that distribution of $\mathrm{B}_{\mathrm{CBE}} / \mathrm{B}_{\mathrm{ABB}}$ values for the territories of oil fields and beyond them is significantly different. For oil filed areas $\mathrm{B}_{\mathrm{CBE}} / \mathrm{B}_{\mathrm{ABB}}$ values in the range of 0.0-4.0 fractions of units are found with a frequency of 0.886 , while for areas beyond the fields - 0.956 . In the range of 2.0-10.0 in the first case 0.041 , in the second -0.042 , i.e. there is a practical equality of the values of the frequency. With $\mathrm{B}_{\mathrm{CBE}} / \mathrm{B}_{\mathrm{ABB}}>12.0$ for the territories of oil fields, the frequency is 0.063 ; there are no such high values beyond the oil fields. The performed evaluation of differences by criterion $\chi^{2}$ showed that the distributions are statistically different. This allowed the use the characteristic to build a probabilistic model.

In accordance with the methodology used at the first stage of constructing a probabilistic model in each interval, the probabilities of belonging to the territories of oil fields are determined $\left(P\left(\mathrm{~B}_{\mathrm{CBE}} / \mathrm{B}_{\mathrm{ABB}}\right)\right)$. Next, interval probabilities of belonging to the $1^{\text {st }}$ class are compared with the average interval values $\mathrm{B}_{\mathrm{CBE}} / \mathrm{B}_{\mathrm{ABB}}$. By magnitude of $P\left(\mathrm{~B}_{\mathrm{CBE}} / \mathrm{B}_{\mathrm{ABB}}\right)$ and $\mathrm{B}_{\mathrm{CBE}} / \mathrm{B}_{\mathrm{ABB}}$ the pair correlation coefficient $r$ is calculated and the regression equation is constructed. The subsequent adjustment of the models built is carried out from the condition that the average value of the probabilities for the territories of oil fields must be greater than 0.5 , and for the territories outside the oil fields less than 0.5. Thus, linear models built for a given strata allowed to evaluate the individual informativity of each geochemical indicator with respect to oil and gas content. An example of a graphic image of the constructed linear model in terms of $\mathrm{B}_{\mathrm{CBE}} / \mathrm{B}_{\mathrm{ABB}}$ is shown in Fig. 1.

This shows that with increasing values of $\mathrm{B}_{\mathrm{CBE}} / \mathrm{B}_{\mathrm{ABB}}$ from 0 to 21 shares, $P$ value $\left(\mathrm{B}_{\mathrm{CBE}} / \mathrm{B}_{\mathrm{ABB}}\right)$ increases from 0.494 to 0.617 .

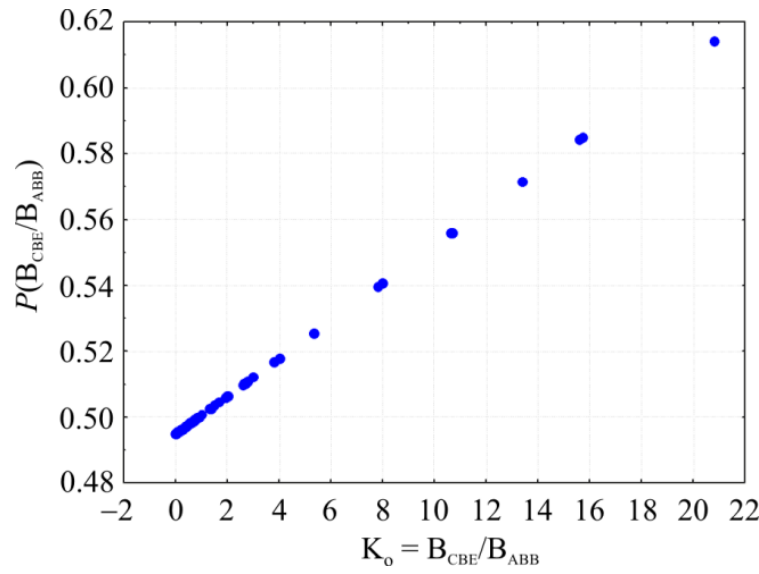

Fig. 1. Dependance $P\left(\mathrm{~B}_{\mathrm{CBE}} / \mathrm{B}_{\mathrm{ABB}}\right)$ on $\mathrm{B}_{\mathrm{CBE}} / \mathrm{B}_{\mathrm{ABB}}$

\section{Building of multidimensional models}

In the next step in forecasting estimates, the authors of the work justified a complex criterion that takes into account the constructed linear individual probabilistic models of each geochemical indicator for this complex. The criterion was calculated by the following formula:

$$
P_{\text {com }}=\frac{\prod P_{\text {ind }}}{\prod P_{\text {ind }}+\prod\left(1-P_{\text {ind }}\right)},
$$

where $P_{\text {ind }}-$ individual probabilities of $P\left(\mathrm{~K}_{\mathrm{c}}\right), P(\mathrm{IR}), P\left(C_{\mathrm{org}}\right), P(\mathrm{OM}), P\left(\mathrm{~B}_{\mathrm{PB}}\right), P\left(\mathrm{~B}_{\mathrm{CBE}}\right)$, $P($ HumA $), P\left(\mathrm{~B}_{\mathrm{CBE}} / \mathrm{B}_{\mathrm{ABB}}\right), P(\beta)$, and $\Pi-$ their multiplication.

A combination of $m$ probabilities was used while calculating a complex criterion $P_{\text {com }}$ for the Upper Devonian-Tournaisian oil and gas complex. Mean values of probabilities $P_{\text {com }}$ in groups are the most statistically different (Table 3 ).

Combinations of probabilities selected in this way, calculated by geochemical indices from $m=2$ to $m=10$, are given in Table 3 . It can be seen from the Table 3 that in the first step of building the model, with $m=2$, the values of $P\left(\mathrm{~B}_{\mathrm{PB}}\right)$ and $P\left(\mathrm{~B}_{\mathrm{ABB}}\right)$ were used, when $m=3$ the $P\left(\mathrm{~K}_{\mathrm{c}}\right)$ probability was included in the model, then following probabilities were consistently included in the model $P\left(\mathrm{~B}_{\mathrm{CBE}} / \mathrm{B}_{\mathrm{ABB}}\right), \quad P\left(\mathrm{~B}_{\mathrm{CBE}}\right), P(\mathrm{IR})$, $P($ HumA $), P(\beta), P\left(C_{\text {org }}\right), P(\mathrm{OM})$.

Dependence of $P_{\text {com }}^{m}$ values on $m$ is given on the Fig. 2.

It is showed that with $m$ increasing from 1 to 6 the average value of $P_{\mathrm{com}}^{m}$ for territories within the field contours regularly grows from 0.515 to 0.533 and remains constant when $m>6$. There is a 
tendency to decrease in values for territories beyond field contours with $m$ increasing. In order to develop a method for calculating $P_{\text {com }}^{m}$ values for the sediments based on the indicators we will use the values $P_{\text {com }}^{m}$ at $m=7$. This is caused by the fact that there is a maximum value of the criterion $t$ with this combination.

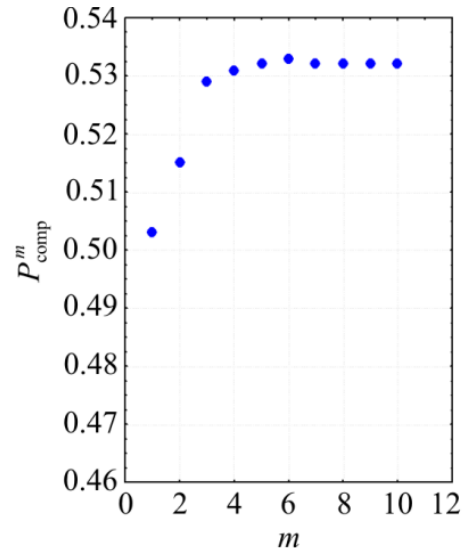

Oil field territoies

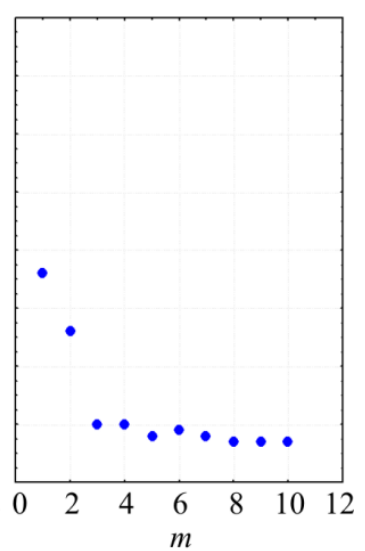

Territories beyond the oil fields
Fig. 2. Dependence of values $P_{\mathrm{com}}^{m}$ on $m$

The need to build a multidimensional model is caused by the fact that the studied indicators have a different effect on the complex criterion $P_{\mathrm{com}}^{m}$ both in strength and in direction
The influence of all the studied parameters was investigated by calculating the correlation coefficients $r$, defined in three options: the first option - according to all data, second - according to geochemical samples taken within the contours of the fields, third - beyond the contours of fields. The results of calculations of the values of $r$ are given in Table 4 .

Table 4 shows that the values of the correlation coefficients $r$ between the studied parameters are different. For example, the correlation between $P_{\text {com }}^{m}$ and $\beta$ for samples taken within field contours has a statistically positive relationship, whereas for samples taken outside field contours, it is also statistically significant, but inverse.

Differences in the direction and closeness of correlations for two classes under the study are also observed between $P_{\text {com }}^{m}$ and other geochemical indicators (see Table 4). It should also be noted that there are different statistical relationships between the indicators that form values $P_{\text {com }}^{m}$ for two classes under the study. For example, the correlation between $\mathrm{B}_{P B}$ and $\mathrm{B}_{C B E}$ for samples taken within the fields' contours has a statistically positive relationship, whereas for samples taken outside the contours of deposits, it is practically absent.

Table 3

The study of combinations of the probability of belonging to a class of territories within field contours at different values of $m$

\begin{tabular}{|c|c|c|c|c|c|c|c|c|c|}
\hline \multirow{2}{*}{ Probability } & \multicolumn{9}{|c|}{ Combination of probabilities with different $m$} \\
\hline & 2 & 3 & 4 & 5 & 6 & 7 & 8 & 9 & 10 \\
\hline$P(\mathrm{IR})$ & & & & & + & + & + & + & + \\
\hline$P\left(C_{\text {org }}\right)$ & & & & & & & & + & + \\
\hline$P(\mathrm{OM})$ & & & & & & & & & + \\
\hline$P\left(\mathrm{~B}_{\mathrm{PB}}\right)$ & + & + & + & + & + & + & + & + & + \\
\hline$P\left(\mathrm{~B}_{\mathrm{CBE}}\right)$ & & & & + & + & + & + & + & + \\
\hline$P\left(\mathrm{~B}_{\mathrm{ABB}}\right)$ & + & + & + & + & + & + & + & + & + \\
\hline$P($ HumA $)$ & & & & & & + & + & + & + \\
\hline$P\left(\mathrm{~B}_{\mathrm{CBE}} / \mathrm{B}_{\mathrm{ABB}}\right)$ & & & + & + & + & + & + & + & + \\
\hline$P(\beta)$ & & & & & & & + & + & + \\
\hline$P\left(\mathrm{~K}_{\mathrm{c}}\right)$ & & + & + & + & + & + & + & + & + \\
\hline $\begin{array}{l}\text { Mean value of the } \\
\text { probability of the } \\
\text { territories within field } \\
\text { contours }\end{array}$ & 0.515 & 0.529 & 0.531 & 0.532 & 0.533 & 0.532 & 0.532 & 0.532 & 0.532 \\
\hline $\begin{array}{l}\text { Mean probability } \\
\text { value for territories } \\
\text { beyons the field } \\
\text { contours }\end{array}$ & 0.486 & 0.470 & 0.470 & 0.468 & 0.469 & 0.468 & 0.467 & 0.467 & 0.467 \\
\hline$\frac{t}{-}$ & $\underline{4.267}$ & $\underline{4.3953}$ & $\underline{4.6082}$ & $\underline{4.7188}$ & $\underline{4.7591}$ & $\underline{4.7792}$ & $\underline{4.7542}$ & $\underline{4.7511}$ & $\underline{4.7445}$ \\
\hline $\bar{p}$ & $0 . \overline{00002}$ & $0 . \overline{000017}$ & $0 . \overline{000007}$ & $0 . \overline{000004}$ & $0 . \overline{000003}$ & $0 . \overline{000003}$ & $0 . \overline{000003}$ & $0 . \overline{000004}$ & 0.000004 \\
\hline
\end{tabular}


Table 4

Correlation Matrix

\begin{tabular}{|c|c|c|c|c|c|c|c|c|c|c|c|}
\hline & $P_{\text {comp }}^{m}$ & $\mathrm{~K}_{\mathrm{c}}$ & IR & $C_{\text {org }}$ & $\mathrm{OM}$ & $\mathrm{B}_{P B}$ & $\mathrm{~B}_{\mathrm{CBE}}$ & $\mathrm{B}_{\mathrm{ABB}}$ & HumA & $\mathrm{B}_{\mathrm{CBE}} / \mathrm{B}_{\mathrm{ABB}}$ & $\beta$ \\
\hline \multirow{3}{*}{$P_{\text {comp }}^{m}$} & 1.00 & $-0.73^{*}$ & $0.28^{*}$ & -0.02 & -0.02 & $\underline{0.50^{*}}$ & $0.29^{*}$ & $0.37^{*}$ & -0.19 & 0.24 & 0.09 \\
\hline & $\overline{1.00}$ & $-0.85^{*}$ & $\underline{0.22}$ & $\overline{0.14}$ & $\underline{0.13}$ & $\underline{0.54^{*}}$ & $0.35^{*}$ & $0.35^{*}$ & -0.00 & $\underline{0.51 *}$ & $0.42^{*}$ \\
\hline & $\overline{1.00}$ & $0.96^{*}$ & $0.57^{*}$ & $-\overline{0.30} *$ & $-\overline{0.31} *$ & $\overline{0.07}$ & $-0.52^{*}$ & -0.22 & $-0.37 *$ & $-0.33^{*}$ & -0.39 \\
\hline \multirow{3}{*}{$K_{c}$} & & 1.00 & $-0.53^{*}$ & 0.16 & 0.17 & 0.16 & 0.23 & 0.21 & 0.10 & 0.03 & $0.25^{*}$ \\
\hline & & $\overline{1.00}$ & $-0.45^{*}$ & -0.09 & -0.08 & $\underline{0.14}$ & $\underline{0.06}$ & $\underline{0.08}$ & -0.01 & -0.21 & -0.11 \\
\hline & & $\overline{1.00}$ & $-0.68^{*}$ & $\overline{0.33^{*}}$ & $\overline{0.34^{*}}$ & $\overline{0.25}$ & $0.63^{*}$ & $\overline{0.42^{*}}$ & $0.26^{*}$ & $\overline{0.42 *}$ & $\overline{0.46}$ \\
\hline \multirow{3}{*}{ IR } & & & 1.00 & $\underline{0.14}$ & $\underline{0.14}$ & -0.22 & -0.10 & -0.25 & $\underline{0.08}$ & -0.12 & $-0.39^{*}$ \\
\hline & & & 1.00 & 0.25 & 0.25 & -0.24 & $\overline{0.04}$ & -0.20 & 0.30 & 0.05 & -0.08 \\
\hline & & & $\overline{1.00}$ & $-\overline{0.01}$ & $-\overline{0.02}$ & -0.15 & $-\overline{0.62} *$ & $-0.52^{*}$ & $-\overline{0.04}$ & $-\overline{0.38} *$ & -0.52 \\
\hline \multirow{3}{*}{$C_{\text {org }}$} & & & & 1.00 & $1.00^{*}$ & $\begin{array}{l}0.10 \\
\end{array}$ & $0.28^{*}$ & $\underline{0.15}$ & 0.11 & 0.02 & -0.11 \\
\hline & & & & 1.00 & $1.00^{*}$ & -0.04 & $0.65^{*}$ & $\underline{0.17}$ & 0.26 & -0.05 & -0.11 \\
\hline & & & & 1.00 & $1.00^{*}$ & $0.41 *$ & 0.26 & $0.43^{*}$ & 0.57 & -0.05 & -0.21 \\
\hline \multirow{3}{*}{$\mathrm{OM}$} & & & & & $\underline{1.00}$ & $\underline{0.10}$ & $\underline{0.28^{*}}$ & $\underline{0.15}$ & $\underline{0.11}$ & $\underline{0.02}$ & -0.11 \\
\hline & & & & & $\overline{1.00}$ & $\overline{\underline{0.04}}$ & $\underline{0.65^{*}}$ & $\overline{0.17}$ & $\overline{0.26}$ & -0.05 & $\overline{-0.11}$ \\
\hline & & & & & $\overline{1.00}$ & $0.41^{*}$ & $\overline{0.26}$ & $0.43^{*}$ & $\overline{0.57}$ & -0.05 & -0.21 \\
\hline \multirow{3}{*}{$\mathrm{B}_{P B}$} & & & & & & 1.00 & $0.45^{*}$ & $0.64^{*}$ & -0.09 & $\underline{0.31 *}$ & $0.33^{*}$ \\
\hline & & & & & & 1.00 & $0.39^{*}$ & -0.06 & $\underline{0.03}$ & 0.64 & $0.48^{*}$ \\
\hline & & & & & & 1.00 & 0.06 & $0.51 *$ & 0.04 & -0.02 & -0.05 \\
\hline \multirow{3}{*}{$\mathrm{B}_{\mathrm{CBE}}$} & & & & & & & 1.00 & $\underline{0.41^{*}}$ & $\underline{0.00}$ & $\underline{0.26^{*}}$ & $\underline{0.32^{*}}$ \\
\hline & & & & & & & 1.00 & $\overline{0.19}$ & $\underline{0.31}$ & $\underline{0.34}$ & $\underline{0.42^{*}}$ \\
\hline & & & & & & & $\overline{1.00}$ & $0.49^{*}$ & $\overline{0.22}$ & $0.47^{*}$ & $0.57^{*}$ \\
\hline \multirow{3}{*}{$\mathrm{B}_{\mathrm{ABB}}$} & & & & & & & & 1.00 & $\underline{0.01}$ & -0.03 & 0.15 \\
\hline & & & & & & & & 1.00 & $\underline{0.13}$ & -0.19 & -0.03 \\
\hline & & & & & & & & $\overline{1.00}$ & $\overline{0.15}$ & $\overline{-0.02}$ & $\overline{0.01}$ \\
\hline \multirow{3}{*}{ HumA } & & & & & & & & & 1.00 & $\underline{-0.05}$ & $\begin{array}{l}-0.11 \\
\end{array}$ \\
\hline & & & & & & & & & $\overline{1.00}$ & $\overline{-0.08}$ & -0.07 \\
\hline & & & & & & & & & $\overline{1.00}$ & $\overline{-0.04}$ & $\overline{0.11}$ \\
\hline \multirow{3}{*}{$\mathrm{B}_{\mathrm{CBE}} / \mathrm{B}_{\mathrm{ABB}}$} & & & & & & & & & & $\underline{1.00}$ & $\underline{0.66^{*}}$ \\
\hline & & & & & & & & & & $\underline{1.00}$ & $\underline{0.90^{*}}$ \\
\hline & & & & & & & & & & 1.00 & $0.75^{*}$ \\
\hline$\beta$ & & & & & & & & & & & $\frac{1.00}{\frac{1.00}{100}}$ \\
\hline
\end{tabular}

Note: the top line is all the data, the middle line is the fields' contour, the bottom line is beyond fields' contour; ${ }^{*}-$ statistically significant correlations.

All these data show that there are statistical differences in both the distributions and correlations for samples taken within the contours of deposits and beyond their contours. Consequently, the oil and gas potential of the Visimskaya monocline depends on the geochemical characteristics of the DOM of the Upper Devonian-Tournaisian sediments. According to the authors of this work, these indicators can be used to produce the zonal oil and gas potential of the study area.

Multidimensional models using step-by-step regression analysis are used in order to account for the diversity of different, and in some cases multidirectional, effects of the studied indicators on $P_{\text {comp }}^{n=7}$. The calculation of the regression coefficients in the developed model is performed using the least squares method.
A regression analysis is a statistical method for studying the dependencies between the dependent variable $Y$ and one or several independent variables $X_{1}, X_{2}, X_{p}$. A dependent attribute in the regression analysis is called resultant, independent - factorial. Usually, several factors act on a dependent variable. The cumulative effect of all independent factors on the dependent variable is taken into account due to multiple regression.

In the general case, multiple regression is estimated by the parameters of the linear equation $Y=a+b_{1} X_{1}+b_{2} X_{2}+\ldots+b_{p} X_{p}$.

In this equation, the regression coefficients (b-coefficients) represent the independent contributions of each independent variable to the prediction of the dependent variable. The regression line expresses the best prediction of the dependent variable $(Y)$ with respect to the independent variables $\left(X_{n}\right)$. 
Values $P_{\text {comp }}^{\mathrm{GC}}$

\begin{tabular}{|c|c|c|c|c|c|c|}
\hline Areas & Well & Age & $\begin{array}{c}\text { Number of } \\
\text { samples }\end{array}$ & $P_{\text {comp }}^{\mathrm{GC}}$ mean & $P_{\text {comp }}^{\mathrm{GC}} \min$ & $P_{\text {comp }}^{\mathrm{GC}} \max$ \\
\hline Visim-Istokskaya & 33 & $\mathrm{D}_{3} \mathrm{f}_{2}-\mathrm{C}_{1} \mathrm{t}$ & 10 & $0.458 \pm 0.164$ & 0.369 & 0.887 \\
\hline Visimskaya & 11 & $\mathrm{D}_{3} \mathrm{f}_{2}-\mathrm{C}_{1} \mathrm{t}$ & 7 & $0.408 \pm 0.043$ & 0.379 & 0.502 \\
\hline Visimskaya & 13 & $\mathrm{D}_{1}-\mathrm{D}_{3} \mathrm{f}_{1}$ & 21 & $0.445 \pm 0.067$ & 0.373 & 0.574 \\
\hline Visimskaya & 14 & $\mathrm{D}_{3} \mathrm{f}_{2}-\mathrm{C}_{1} \mathrm{t}$ & 9 & $0.467 \pm 0.087$ & 0.379 & 0.646 \\
\hline Visimskaya & 15 & $\mathrm{D}_{3} \mathrm{f}_{2}-\mathrm{C}_{1} \mathrm{t}$ & 21 & $0.536 \pm 0.111$ & 0.381 & 0.695 \\
\hline Visimskaya & 16 & $\mathrm{D}_{3} \mathrm{f}_{2}-\mathrm{C}_{1} \mathrm{t}$ & 17 & $0.556 \pm 0.157$ & 0.397 & 0.972 \\
\hline Visimskaya & 23 & $\mathrm{D}_{3} \mathrm{f}_{2}-\mathrm{C}_{1} \mathrm{t}$ & 2 & $0.384 \pm 0.008$ & 0.378 & 0.390 \\
\hline Garinskaya & 62 & $\mathrm{D}_{1}-\mathrm{D}_{3} \mathrm{f}_{1}$ & 27 & $0.552 \pm 0.012$ & 0.540 & 0.581 \\
\hline Dmitrievskaya & 2 & $\mathrm{D}_{3} \mathrm{f}_{2}-\mathrm{C}_{1} \mathrm{t}$ & 7 & $0.545 \pm 0.003$ & 0.542 & 0.551 \\
\hline Dmitrievskaya & 5 & $\mathrm{D}_{3} \mathrm{f}_{2}-\mathrm{C}_{1} \mathrm{t}$ & 3 & $0.384 \pm 0.015$ & 0.369 & 0.401 \\
\hline Invinskaya & 71 & $\mathrm{D}_{3} \mathrm{f}_{2}-\mathrm{C}_{1} \mathrm{t}$ & 6 & $0.387 \pm 0.016$ & 0.370 & 0.413 \\
\hline Karnashevskaya & 90 & $\mathrm{D}_{3} \mathrm{f}_{2}-\mathrm{C}_{1} \mathrm{t}$ & 7 & $0.378 \pm 0.021$ & 0.363 & 0.410 \\
\hline Kasibskaya & 15 & $\mathrm{D}_{3} \mathrm{f}_{2}-\mathrm{C}_{1} \mathrm{t}$ & 4 & $0.411 \pm 0.013$ & 0.393 & 0.421 \\
\hline Kasibskaya & 2 & $\mathrm{D}_{3} \mathrm{f}_{2}-\mathrm{C}_{1} \mathrm{t}$ & 2 & $0.390 \pm 0.025$ & 0.372 & 0.409 \\
\hline Kasibskaya & 3 & $\mathrm{D}_{1}-\mathrm{D}_{3} \mathrm{f}_{1}$ & 6 & $0.573 \pm 0.018$ & 0.548 & 0.592 \\
\hline Kuprosskaya & 9 & $\mathrm{D}_{1}-\mathrm{D}_{3} \mathrm{f}_{1}$ & 13 & $0.552 \pm 0.007$ & 0.546 & 0.562 \\
\hline Mayikorskaya & 13 & $\mathrm{D}_{3} \mathrm{f}_{2}-\mathrm{C}_{1} \mathrm{t}$ & 6 & $0.794 \pm 0.212$ & 0.373 & 0.982 \\
\hline Nazarovskaya & Durinskaya & $\mathrm{D}_{3} \mathrm{f}_{2}-\mathrm{C}_{1} \mathrm{t}$ & 16 & $0.385 \pm 0.022$ & 0.346 & 0.442 \\
\hline Nazarovskaya & Ivazhinskaya & $\mathrm{D}_{1}-\mathrm{D}_{3} \mathrm{f}_{1} ; \mathrm{D}_{3} \mathrm{f}_{2}-\mathrm{C}_{1} \mathrm{t}$ & 30 & $0.434 \pm 0.077$ & 0.366 & 0.561 \\
\hline Nylobsko-Urayskaya & 17 & $\mathrm{D}_{1}-\mathrm{D}_{3} \mathrm{f}_{1} ; \mathrm{D}_{3} \mathrm{f}_{2}-\mathrm{C}_{1} \mathrm{t}$ & 14 & $0.434 \pm 0.086$ & 0.369 & 0.548 \\
\hline Rodnikovskaya & 12 & $\mathrm{D}_{3} \mathrm{f}_{2}-\mathrm{C}_{1} \mathrm{t}$ & 1 & 0.369 & & \\
\hline Romanshorskaya & 1 & $\mathrm{D}_{3} \mathrm{f}_{2}-\mathrm{C}_{1} \mathrm{t}$ & 16 & $0.552 \pm 0.060$ & 0.372 & 0.696 \\
\hline \begin{tabular}{|l|} 
Senkinskaya \\
\end{tabular} & Belopashninskaya & $\mathrm{D}_{1}-\mathrm{D}_{3} \mathrm{f}_{1}$ & 4 & $0.553 \pm 0.015$ & 0.533 & 0.576 \\
\hline Slutskaya & 279 & $\mathrm{D}_{1}-\mathrm{D}_{3} \mathrm{f}_{1} ; \mathrm{D}_{3} \mathrm{f}_{2}-\mathrm{C}_{1} \mathrm{t}$ & 18 & $0.423 \pm 0.062$ & 0.375 & 0.558 \\
\hline Tukachevskaya & 3 & $\mathrm{D}_{1}-\mathrm{D}_{3} \mathrm{f}_{1}$ & 10 & $0.560 \pm 0.015$ & 0.546 & 0.584 \\
\hline \begin{tabular}{|l|} 
Ust-Kondasskaya \\
\end{tabular} & 3 & $\mathrm{D}_{3} \mathrm{f}_{2}-\mathrm{C}_{1} \mathrm{t}$ & 3 & $0.489 \pm 0.090$ & 0.385 & 0.543 \\
\hline Chermozskaya & 3 & $\mathrm{D}_{1}-\mathrm{D}_{3} \mathrm{f}_{1} ; \mathrm{D}_{3} \mathrm{f}_{2}-\mathrm{C}_{1} \mathrm{t}$ & 14 & $0.585 \pm 0.043$ & 0.544 & 0.691 \\
\hline Shatovskaya & 287 & $\mathrm{D}_{1}-\mathrm{D}_{3} \mathrm{f}_{1} ; \mathrm{D}_{3} \mathrm{f}_{2}-\mathrm{C}_{1} \mathrm{t}$ & 22 & $0.524 \pm 0.110$ & 0.371 & 0.808 \\
\hline Shatovskaya & 293 & $\mathrm{D}_{3} \mathrm{f}_{2}-\mathrm{C}_{1} \mathrm{t}$ & 9 & $0.412 \pm 0.066$ & 0.374 & 0.586 \\
\hline
\end{tabular}

Table 6

Distribution of values $P_{\text {comp }}^{\mathrm{GC}}$ mean, $P_{\text {comp }}^{\mathrm{GC}} \min , P_{\text {comp }}^{\mathrm{GC}} \max$

\begin{tabular}{|l|c|c|c|c|c|c|c|c|c|c|}
\hline \multirow{2}{*}{$P_{\text {comp }}^{\mathrm{GC}}$} & \multicolumn{9}{|c|}{ Variation intervals $P_{\text {comp }}^{\mathrm{GC}}$} \\
\cline { 2 - 12 } & $0.0-0.1$ & $0.1-0.2$ & $0.2-0.3$ & $0.3-0.4$ & $0.4-0.5$ & $0.5-0.6$ & $0.6-0.7$ & $0.7-0.8$ & $0.8-0.9$ & $0.9-1.0$ \\
\hline Mean & - & - & - & 0.241 & 0.351 & 0.373 & - & 0.035 & - & - \\
\hline Min & - & - & - & 0.758 & - & 0.242 & - & - & - & - \\
\hline Max & - & - & - & 0.068 & 0.208 & 0.448 & 0.138 & - & 0.069 & 0.069 \\
\hline
\end{tabular}

In our case, $P_{\text {comp }}^{\mathrm{GC}-m=7}$ is a dependent attribute, and values of $\mathrm{K}_{\mathrm{c}}, \mathrm{IR}, C_{\mathrm{org}}, \mathrm{OM}, \mathrm{B}_{\mathrm{PB}}, \mathrm{B}_{\mathrm{CBE}}$, HumA, $\mathrm{B}_{\mathrm{CBE}} / \mathrm{B}_{\mathrm{ABB}}, \beta$ as independent factors.

The model derives based on geochemical characteristics of the DOM of the Upper DevonianTournaisan sediments has the following formula

$$
\begin{gathered}
P_{\text {comp }}^{\mathrm{GC}}=2.952-2.26761 \mathrm{~K}_{\mathrm{c}}+2.26761 \mathrm{~B}_{\mathrm{PB}}+ \\
\quad+0.16153 \mathrm{~B}_{\mathrm{CBE}}+0.22506 \mathrm{~B}_{\mathrm{ABB}}+ \\
+0.000742 \mathrm{~B}_{\mathrm{CBE}} / \mathrm{B}_{\mathrm{ABB}}-0.45018 \mathrm{HumA}- \\
-0.00005 \mathrm{IR}+0.00005 \beta+0.0001 \mathrm{OM}
\end{gathered}
$$

if $R=0.999, p<0,0000$, forecast error is 0.00311 .
The sequence of input of indicators in regression equations was done in a sequence of indicators given in the equation. In the first step of equation formulation, the indicator $\mathrm{K}_{\mathrm{c}}$ was included when $R=0.726$; further, the value of $R$ was changed as follows: $0.956 ; 0.981 ; 0.991$; 0.994; 0.996; 0.997; 0.998; 0.999 .

Using this model, the $P_{\text {comp }}^{\mathrm{GC}}$ values for all geochemical samples taken from these sediments were calculated. Information on well numbers from which samples were taken, age, their number and $P_{\text {comp }}^{\mathrm{GC}}$ values is given in Table 5. 


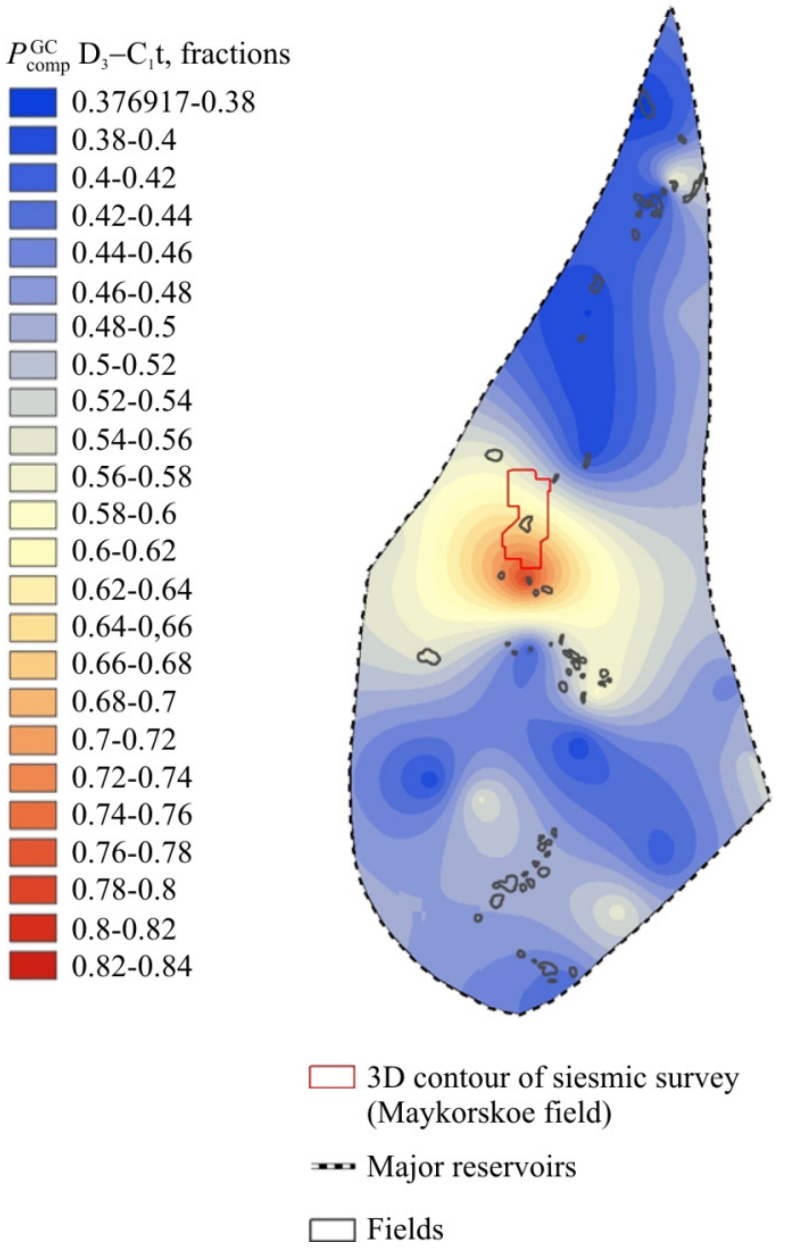

Fig. 3. Scheme of the oil and gas distribution probability on geochemical and bitumen characteristics for Visimskaya monocline territory
According to 29 wells and 322 determinations of DOM indicators, the average value of $P_{\text {comp }}^{\mathrm{GC}}=$ $=0.480 \pm 0.094$; it varies from 0.346 to 0.982 .

According to the Table 5 plotted density distribution of values $P_{\text {comp }}^{\mathrm{GC}}$ mean, $P_{\text {comp }}^{\mathrm{GC}} \min , P_{\text {comp }}^{\mathrm{GC}}$ max, are given in Table 6.

This shows that $P_{\text {comp }}^{\mathrm{GC}}$ values in all three cases change slightly. For example, the mean probability in most cases has values in the range 0.4-0.6 (0.724). The average values in the wells were used to construct a pattern of oil and gas potential distribution for the territory of the Visimskaya monocline (Fig. 3).

\section{Conclusion}

As a result of the studies performed, it was found that the most favorable geochemical conditions for the formation of petroleum potential due to DOM are observed in the central part of the Visimskaya monocline, within the Maykorskoye field and the area around it, limited by the probability level greater than 0.5 .

Territories in the south of the Visimskaya monocline where $P_{\text {comp }}^{\mathrm{GC}}>0.5$ are of particular interest in terms of zonal petroleum potential. Probably, there is a certain interest in the territory in the north of the Visimskaya monocline. This scheme will be used in further assessments of zonal oil and gas potential of the Visimskaya monocline.

\section{References}

1. Galkin V.I., Rastegaev A.V., Galkin S.V. Veroyatnostno-statisticheskaya otsenka neftegazonosnosti lokalnykh struktur [Probabilistic-statistical evaluation of the gas content of local structures]. Ekaterinburg, 2001, 277 p.

2. Kozlova I.A., Galkin V.I., Vantseva I.V. K otsenke perspektiv neftegazonosnosti Solikamskoy depressii s pomoshchyu geologo-geokhimicheskikh kharakteristik neftegazomaterinskikh porod [On the assessment of the prospects for the oil and gas potential of the Solikamsk Depression using the geological and geochemical characteristics of the oil and gas source rocks]. Oilfield engineering, 2010, no.7, pp.20-23.

3. Krivoshchekov S.N., Galkin V.I., Nosov M.A. Otsenka nelokalizovannykh resursov nefti territorii Permskogo kraya pri pomoshchi sistemy elementarnykh uchastkov [Evaluation of non-localized oil resources in Perm Region by a system of elementary sections]. Oil industry, 2014, no.6, pp.9-11.

4. Krivoshchekov S.N., Kozlova I.A., Sannikov I.V. Otsenka perspektiv neftegazonosnosti zapadnoy chasti Solikamskoy depressii na osnove geokhimicheskikh i geodinamicheskikh dannykh [Estimate of the petroleum potential of the western Solikamsk depression based on geochemical and geodynamic data]. Oil industry, 2014, no.6, pp.12-15.

5. Galkin V.I., Kozlova I.A., Melkishev O.A., Shadrina M.A. Geokhimicheskie pokazateli ROV porod kak kriterii otsenki perspektiv neftegazonosnosti [Geochemical indicators of rock DOM as criteria for evaluating oil and gas potential]. Oilfield engineering, 2013, no.9, pp.28-31.

6. Kozlova I.A., Melkishev O.A. Prognoznaia otsenka raspredeleniia nelokalizovannykh resursov nefti v devonskom terrigennom komplekse na territorii Permskogo kraia [Predictive estimation of non-localized oil resources distribution in the Devonian terrigenous complex in Perm region]. Geologiya, geofizika $i$ razrabotka neftyanykh $i$ gazovykh mestorozhdeniy, 2017, no.2, pp.4-8.

7. Galkin V.I., Kozlova I.A. Razrabotka veroiatnostnostatisticheskikh regionalno-zonalnykh modelei prognoza neftegazonosnosti po dannym geokhimicheskikh issledovanii verkhnedevonskikh karbonatnykh otlozhenii [Development of probabilistic-statistical regional-zoning models of oil and gas potential prediction based on the data of geochemical studies of the Upper Devonian carbonate deposits]. 
Geologiya, geofizika $i$ razrabotka neftyanykh $i$ gazovykh mestorozhdeniy, 2016, no.6, pp.40-45.

8. Galkin V.I., Kozlova I.A., Krivoshchekov S.N., Nosov M.A., Koltyrina N.S. Otsenka perspektiv neftegazonosnosti iuga Permskogo kraia po organo-geokhimicheskim dannym [Estimation of petroleum potential prospects in the south of Perm territory on the basis of organic-geochemical data]. Oilfield engineering, 2015, no.7, pp.32-35.

9. Galkin V.I., Kozlova I.A., Krivoshchekov S.N., Nosov M.A. Reshenie regionalnykh zadach prognozirovaniya neftenosnosti po dannym geologo-geokhimicheskogo analiza rasseyannogo organicheskogo veshchestva porod domanikovogo tipa [Solutions to regional problems of forecasting oil bearing according to geological and geochemical analysis of dispersed organic matter of Domanic type rocks]. Oil industry, 2015, no.1, pp.21-23.

10. Galkin V.I., Kozlova I.A., Krivoshchekov S.N., Melkishev O.A. K obosnovaniyu postroeniya modeley zonalnogo prognoza neftegazonosnosti dlya nizhnesrednevizeyskogo kompleksa Permskogo kraya [On the justification of the construction of models for oil and gas potential area forecast Visean deposits of Perm region]. Oil industry, 2015, no.8, pp.32-35.

11. Galkin V.I., Zhukov Yu.A., Shishkin M.A. Primenenie veroyatnostnykh modeley dlya lokalnogo prognoza neftegazonosnosti [Application of probabilistic models for local prediction of oil and gas potential]. Ekaterinburg, URo RAN, 1990, 108 p.

12. Brodiagin V.V., Potriasov A.A., Skachek K.G., Shaikhutdinov A.N. Zonalnyi prognoz neftegazonosnosti iurskikh otlozhenii $\mathrm{v}$ predelakh territorii deiatelnosti tpp "Kogalymneftegaz" [Zonal forecast of the oil and gas potential of the Jurassic sediments within the territory of activity of the CCI "Kogalymneftegas". Geologiia, geofizika i razrabotka neftianykh i gazovykh mestorozhdenii, 2008, no.8, pp.31-35.

13. Galkin V.I., Shaykhutdinov A.N. O vozmozhnosti prognoza neftegazonosnosti yurskikh otlozheniy veroyatnostno-statisticheskimi metodami (na primere territorii deyatelnosti TPP "Kogalymneftegaz") [About possibility to forecast the oil-and-gas content of jurassic sediments based on probable and statistical methods (case study of the territorial industrial enterprise "Kogalymneftegas")]. Geologiia, geofizika i razrabotka neftianykh i gazovykh mestorozhdenii, 2009, no.6, pp.11-14.

14. Galkin V.I., Shaikhutdinov A.N. Postroenie statisticheskikh modelei dlia prognoza debitov nefti po verkhneiurskim otlozheniiam Kogalymskogo regiona [Development of statistical models for predicting the oil flow rates by example jurassic deposits of Kogalym region territory]. Oil industry, 2010, no.1, pp.52-54.

15. Galkin V.I., Krivoshchekov S.N. Postroenie matritsy elementarnykh iacheek pri prognoze neftegazonosnosti veroiatnostno-statisticheskimi metodami na territorii Permskogo kraia [Construction of a matrix of elementary cells in the prediction of oil and gas potential by probabilisticstatistical methods on the territory of the Perm Territory]. Geologiia, geofizika $i$ razrabotka neftianykh $i$ gazovykh mestorozhdenii, 2008, no.8, pp.20-23.
16. Galkin V.I., Krivoshchekov S.N. Obosnovanie napravlenii poiskov mestorozhdenii nefti $\mathrm{i}$ gaza $\mathrm{V}$ Permskom krae [Justification of the direction of the search for oil and gas in the Perm region]. Nauchnye issledovaniya i innovatsii, Perm, 2009, vol.3, no.4, pp.3-7.

17. Galkin V.I., Kozlova I.A., Rastegaev A.V., Vantseva I.V., Krivoshchekov S.N., Voevodkin V.L. $\mathrm{K}$ metodike otsenki perspektiv neftegazonosnosti Solikamskoy depressii po kharakteristikam lokalnykh struktur [Estimation procedure of petroleum potential of solikamsk depression based on local structures parameters]. Oilfield engineering, 2010, no.7, pp.12-17.

18. Galkin V.I., Rastegaev A.V., Kozlova I.A., Vantseva I.V., Krivoshchekov S.N., Voevodkin V.L. prognoznaia otsenka neftegazonosnosti struktur na territorii Solikamskoi depressii [Probable estimation of oil content of structures in territory of Solikamsk depression]. Oilfield engineering, 2010, no.7, pp.4-7.

19. Belokon T.V., Galkin V.I., Kozlova I.A., Pashkova S.E. Dodevonskie otlozheniia Permskogo Prikamia kak odno iz perspektivnykh napravlenii geologorazvedochnykh rabot [Pre-Devonian deposits of the Perm Prikamye as one of the promising areas of geological exploration]. Geologiia, geofizika i razrabotka neftianykh $i$ gazovykh mestorozhdenii, 2005, no.9, pp.24-28.

20. Putilov I.S. Razrabotka tekhnologii kompleksnogo izucheniia geologicheskogo stroeniia $i$ razmeshcheniia mestorozhdenii nefti i gaza [Development of technologies for the integrated study of the geological structure and location of oil and gas fields]. Perm', Izdatel'stvo Permskogo natsional'nogo issledovatel'skogo politekhnicheskogo universiteta, 2014, 285 p.

21. Galkin V.I., Kozlova I.A., Krivoshchekov S.N., Pyatunina E.V., Pestova S.N. O vozmozhnosti prognozirovaniya neftegazonosnosti famenskikh otlozheniy $\mathrm{s}$ pomoshchyu postroeniya veroyatnostnostatisticheskikh modeley [On the possibility of predicting the petroleum potential of the Famennian sediments using the construction of probabilistic-statistical models]. Geologiia, geofizika i razrabotka neftianykh $i$ gazovykh mestorozhdenii, 2007, no.10, pp.22-27.

22. Galkin V.I., Solov'ev S.I. Classification of Perm krai areas according to prospectivity for oil fields acquisition. Perm Journal of Petroleum and Mining Engineering, 2015, no.16, pp.14-24. DOI: 10.15593/224-9923/2015.16.2

23. Sosnin N.E. Development of statistical models for predicting oil-and-gas content (on the example of terrigenous devonian sediments of North Tatar arch). Perm Journal of Petroleum and Mining Engineering, 2012, no.5, pp.16-25.

24. Galkin V.I., Sosnin N.E. Razrabotka geologomatematicheskikh modelei dlia prognoza neftegazonosnosti slozhnopostroennykh struktur v devonskikh terrigennykh otlozheniiakh [Geological development of mathematical models for the prediction of oil and gas complex-built structures in the Devonian clastic sediments]. Oil industry, 2013, no.4, pp.28-31.

25. Dementev L.F. Matematicheskie metody i EVM v neftegazovoy geologii [Mathematical methods and computers in oil and gas geology]. Moscow, Nedra, 1987, 264 p. 
26. Davydenko A.Yu. Veroyatnostno-statisticheskie metody V geologo-geofizicheskikh prilozheniyakh [Probabilistic-statistical methods in geological and geophysical applications]. Irkutsk, 2007, 29 p.

27. Mikhalevich I.M. Primenenie matematicheskikh metodov pri analize geologicheskoi informatsii (s ispolzovaniem kompiuternykh tekhnologii) [Use of mathematical methods in the analysis of geological information (using computer technology)]. Irkutsk, 2006, 115 p.

28. Andreiko S.S. Development of mathematical model of gas-dynamic phenomena forecasting method according to geological data in conditions of Verkhnekamskoie potash salt deposit. Perm Journal of Petroleum and Mining Engineering, 2016, no.21, pp.345-353. DOI: 10.15593/224-9923/2016.21.6

29. Devis Dzh. Statistika i analiz geologicheskikh dannykh [Statistics and analysis of geological data]. Moscow, Mir, 1977, 353 p.

30. Pomorskiy Yu.L. Metody statisticheskogo analiza eksperimentalnykh dannykh [Methods of statistical analysis of experimental data]. Leningrad, 1960, $174 \mathrm{p}$.

31. Cherepanov S.S. Integrated research of carbonate reservoir racturing by Warren - Root method using seismic facies analysis (evidence from tournaisianfamennian deposit of Ozernoe field). Perm Journal of Petroleum and Mining Engineering, 2015, no.14, pp.6-12. DOI: $10.15593 / 224-9923 / 2015.14 .1$

32. Galkin V.I., Ponomareva I.N., Cherepanov S.S. Development of the methodology for evaluation of possibilities to determine reservoir types based on pressure build-up curves, geological and reservoir properties of the formation (case study of famen deposits of Ozernoe field). Perm Journal of Petroleum and Mining Engineering, 2015, no.17, pp.32-40. DOI: 10.15593/224-9923/2015.17.4

33. Cherepanov S.S., Martyushev D.A., Ponomareva I.N. Otsenka filtratsionno-emkostnykh svoystv treshchinovatykh karbonatnykh kollektorov mestorozhdeniy Preduralskogo kraevogo progiba [Evaluation of filtration-capacitive properties of fractured carbonate reservoir of Predural'skogo edge deflection]. Oil industry, 2013, no.3, pp.62-65.

34. Galkin V.I., Kunitskikh A.A. Statistical modelling of expanding cement slurry. Perm Journal of Petroleum and Mining Engineering, 2017, vol.16, no.3, pp.215-244. DOI: $10.15593 / 224-9923 / 2017.3 .2$
35. Galkin V.I., Ponomareva I.N., Repina V.A. Study of oil recovery from reservoirs of different void types with use of multidimensional statistical analysis. Perm Journal of Petroleum and Mining Engineering, 2016, no.19, pp.145-154. DOI: 10.15593/224-9923/2016.19.5

36. Krivoshchekov S.N., Galkin V.I. Postroenie matritsy elementarnykh yacheek pri prognoze neftegazonosnosti veroyatnostno-statisticheskimi metodami na territorii Permskogo kraya [Construction of a matrix of elementary cells in the prediction of oil and gas potential by probabilisticstatistical methods on the territory of the Perm Territory]. Geologiia, geofizika $i$ razrabotka neftianykh $i$ gazovykh mestorozhdenii, 2008, no.8, pp.20-23.

37. Ivanov S.A., Rastegaev A.V., Galkin V.I. Analiz rezultatov primeneniya GRP (na primere Povkhovskogo mestorozhdeniya nefti) [Analysis of results of applying formation hydraulic fracturing in povkhovsky oil field]. Oilfield engineering, 2010, no.7, pp.54-58.

38. Krivoshchekov S.N., Galkin V.I., Volkova A.S. Razrabotka veroiatnostno-statisticheskoi metodiki prognoza neftegazonosnosti struktur [Development of a probabilistic-statistical method for predicting the oil and gas potential of structures]. Oilfield engineering, 2010, no.7, pp.28-31.

39. Houze O., Viturat D., Fjaere O.S. Dinamie data analysis. Paris, Kappa Engineering, 2008, 694 p.

40. Van Golf-Racht T.D. Fundamentals of fractured reservoir engineering. Elsevier scientific publishing company. Amsterdam, Oxford, New York, 1982, 709 p.

41. Horne R.N. Modern well test analysis: A computer Aided Approach. $2^{\text {nd }}$ ed. Palo Alto, PetrowayInc, 2006, $257 \mathrm{p}$.

42. Johnson N.L., Leone F.C. Statistics and experimental design. New York, London, Sydney, Toronto, 1977, $606 \mathrm{p}$.

43. Montgomery D.C., Peck E.A., Introduction to liner regression analysis. New York, John Wiley \& Sons, 1982, $504 \mathrm{p}$.

44. Darling T. Well logging and formation evalution. GardnersBooks, 2010, 336 p.

45. Watson G.S. Statistic on spheres. New York, John Wiley and Sons, Inc., 1983, 238 p.

46. Yarus J.M. Stochastic modeling and geostatistics. AAPG. Tulsa, Oklahoma, 1994, 231 p.

\section{Библиографический список}

1. Галкин В.И., Растегаев А.В., Галкин С.В. Вероятностно-статистическая оценка нефтегазоносности локальных структур / УрО РАН. - Екатеринбург, 2001. $277 \mathrm{c}$.

2. Козлова И.А., Галкин В.И., Ванцева И.В. К оценке перспектив нефтегазоносности Соликамской депрессии с помощью геолого-геохимических характеристик нефтегазоматеринских пород // Нефтепромысловое дело. - 2010. - № 7. - С. 20-23.

3. Кривощеков С.Н., Галкин В.И., Носов М.А. Оценка нелокализованных ресурсов нефти территории Пермского края при помощи системы элементарных участков // Нефтяное хозяйство. - 2014. - № 6. - С. 9-11.
4. Кривощеков С.Н., Козлова И.А., Санников И.В. Оценка перспектив нефтегазоносности западной части Соликамской депрессии на основе геохимических и геодинамических данных // Нефтяное хозяйство. 2014. - № 6. - С. 12-15.

5. Геохимические показатели РОВ пород как критерии оценки перспектив нефтегазоносности / В.И. Галкин, И.А. Козлова, О.А. Мелкишев, М.А. Шадрина // Нефтепромысловое дело. - 2013. № 9. - С. 28-31.

6. Козлова И.А., Мелкишев О.А. Прогнозная оценка распределения нелокализованных ресурсов нефти в девонском терригенном комплексе на 
территории Пермского края // Геология, геофизика и разработка нефтяных и газовых месторождений. 2017. - № 2. - C. 4-8.

7. Галкин В.И., Козлова И.А. Разработка вероятностно-статистических регионально-зональных моделей прогноза нефтегазоносности по данным геохимических исследований верхнедевонских карбонатных отложений // Геология, геофизика и разработка нефтяных и газовых месторождений. - 2016. - № 6. C. $40-45$.

8. Оценка перспектив нефтегазоносности юга Пермского края по органогеохимическим данным / В.И. Галкин, И.А. Козлова, С.Н. Кривощеков, М.А. Носов, Н.С. Колтырина // Нефтепромысловое дело. - 2015. - № 7. - С. 32-35.

9. Решение региональных задач прогнозирования нефтеносности по данным геолого-геохимического анализа рассеянного органического вещества пород доманикового типа / В.И. Галкин, И.А. Козлова, С.Н. Кривощеков, М.А. Носов // Нефтяное хозяйство. 2015. - № 1. - С. 21-23.

10. К обоснованию построения моделей зонального прогноза нефтегазоносности для нижнесредневизейского комплекса Пермского края / В.И. Галкин, И.А. Козлова, С.Н. Кривощеков, О.А. Мелкишев // Нефтяное хозяйство. - 2015. № 8. - C. 32-35.

11. Галкин В.И., Жуков Ю.А., Шишкин М.А. Применение вероятностных моделей для локального прогноза нефтегазоносности / Уро РАН. - Екатеринбург, 1990. - $108 \mathrm{c}$.

12. Зональный прогноз нефтегазоносности юрских отложений в пределах территории деятельности ТПП «Когалымнефтегаз» / В.В. Бродягин, А.А. Потрясов, К.Г. Скачек, А.Н. Шайхутдинов // Геология, геофизика и разработка нефтяных и газовых месторождений. 2008. - № 8. - С. 31-35.

13. Галкин В.И., Шайхутдинов А.Н. О возможности прогноза нефтегазоносности юрских отложений вероятностно-статистическими методами (на примере территории деятельности ТПП «Когалымнефтегаз») // Геология, геофизика и разработка нефтяных и газовых месторождений. -2009. - № 6. - С. 11-14.

14. Галкин В.И., Шайхутдинов А.Н. Построение статистических моделей для прогноза дебитов нефти по верхнеюрским отложениям Когалымского региона // Нефтяное хозяйство. -2010 . - № 1. - С. 52-54.

15. Галкин В.И., Кривощеков С.Н. Построение матрицы элементарных ячеек при прогнозе нефтегазоносности вероятностно-статистическими методами на территории Пермского края // Геология, геофизика и разработка нефтяных и газовых месторождений. - 2008. - № 8. - С. 20-23.

16. Галкин В.И., Кривощеков С.Н. Обоснование направлений поисков месторождений нефти и газа в Пермском крае // Научные исследования и инновации. Пермь, 2009. - Т. 3, № 4. - С. 3-7.

17. K методике оценки перспектив нефтегазоносности Соликамской депрессии по характеристикам локальных структур / В.И. Галкин, И.А. Козлова, А.В. Растегаев, И.В. Ванцева, С.Н. Кривощеков, В.Л. Воеводкин // Нефтепромысловое дело. - 2010. № 7. - C. 12-17.

18. Прогнозная оценка нефтегазоносности структур на территории Соликамской депрессии / В.И. Галкин, А.В. Растегаев, И.А. Козлова, И.В. Ванцева, С.Н. Кривощеков, В.Л. Воеводкин // Нефтепромысловое дело. - 2010. - № 7. - С. 4-7.

19. Додевонские отложения Пермского Прикамья как одно из перспективных направлений геологоразведочных работ / Т.В. Белоконь, В.И. Галкин, И.А. Козлова, С.Е. Пашкова // Геология, геофизика и разработка нефтяных и газовых месторождений. 2005. - № 9. - C. 24-28.

20. Путилов И.С. Разработка технологий комплексного изучения геологического строения и размещения месторождений нефти и газа. - Пермь: Изд-во Перм. нац. исслед. политехн. ун-та, 2014. - 285 с.

21. О возможности прогнозирования нефтегазоносности фаменских отложений с помощью построения вероятностно-статистических моделей / В.И. Галкин, И.А. Козлова, С.Н. Кривощеков, Е.В. Пятунина, С.Н. Пестова // Геология, геофизика и разработка нефтяных и газовых месторождений. 2007. - № 10. - C. 22-27.

22. Галкин В.И., Соловьев С.И. Районирование территории Пермского края по степени перспективности приобретения нефтяных участков недр // Вестник Пермского национального исследовательского политехнического университета. Геология. Нефтегазовое и горное дело. - 2015. - № 16. - С. 14-24. DOI: $10.15593 / 224-9923 / 2015.16 .2$

23. Соснин Н.Е. Разработка статистических моделей для прогноза нефтегазоносности (на примере терригенных девонских отложений Северо-Татарского свода) // Вестник Пермского национального исследовательского политехнического университета. Геология. Нефтегазовое и горное дело. - 2012. - № 5. - С. 16-25.

24. Галкин В.И., Соснин Н.Е. Разработка геологоматематических моделей для прогноза нефтегазоносности сложнопостроенных структур в девонских терригенных отложениях // Нефтяное хозяйство. 2013. - № 4. - C. 28-31.

25. Дементьев Л.Ф. Математические методы и ЭВМ в нефтегазовой геологии. - М.: Недра, 1987. - 264 с.

26. Давыденко А.Ю. Вероятностно-статистические методы в геолого-геофизических приложениях. Иркутск, 2007. - 29 с.

27. Михалевич И.М. Применение математических методов при анализе геологической информации (с использованием компьютерных технологий). Иркутск, 2006. - 115 с.

28. Андрейко С.C. Разработка математической модели метода прогнозирования газодинамических явлений по геологическим данным для условий Верхнекамского месторождения калийных солей // Вестник Пермского национального исследовательского политехнического университета. Геология. 
Нефтегазовое и горное дело. - 2016. - № 21. C. 345-353. DOI: 10.15593/224-9923/2016.21.6

29. Девис Дж. Статистика и анализ геологических данных. - М.: Мир, 1977. - 353 с.

30. Поморский Ю.Л. Методы статистического анализа экспериментальных данных: монография. Л., 1960. - 174 c.

31. Черепанов С.С. Комплексное изучение трещиноватости карбонатных залежей методом Уоррена - Рута с использованием данных сейсмофациального анализа (на примере турнефаменской залежи Озерного месторождения) // Вестник Пермского национального исследовательского политехнического университета. Геология. Нефтегазовое и горное дело. - 2015. - № 14. C. 6-12. DOI: 10.15593/224-9923/2015.14.1

32. Галкин В.И., Пономарева И.Н., Черепанов С.С. Разработка методики оценки возможностей выделения типов коллекторов по данным кривых восстановления давления по геолого-промысловым характеристикам пласта // Вестник Пермского национального исследовательского политехнического университета. Геология. Нефтегазовое и горное дело. - 2015. - № 17. C. 32-40. DOI: 10.15593/224-9923/2015.17.4

33. Черепанов С.С., Мартюшев Д.А., Пономарева И.Н. Оценка фильтрационно-емкостных свойств трещиноватых карбонатных коллекторов месторождений Предуральского краевого прогиба // Нефтяное хозяйство. 2013. - № 3. - С. 62-65.

34. Галкин В.И., Куницких В.И. Статистическое моделирование расширяющегося тампонажного состава // Вестник Пермского национального исследовательского политехнического университета. Геология. Нефтегазовое и горное дело. - 2017. - Т. 16, № 3. - C. 215-244. DOI: 10.15593/224-9923/2017.3.2

35. Галкин В.И., Пономарева И.Н., Репина В.А. Исследование процесса нефтеизвлечения в коллекторах различного типа пустотности с использованием многомерного статистического анализа // Вестник Пермского национального исследовательского политехнического университета. Геология. Нефтегазовое и горное дело. - 2016. - № 19. - С. 145-154. DOI: $10.15593 / 224-9923 / 2016.19 .5$

36. Кривощеков С.Н., Галкин В.И. Построение матрицы элементарных ячеек при прогнозе нефтегазоносности вероятностно-статистическими методами на территории Пермского края // Геология, геофизика и разработка нефтяных и газовых месторождений. - 2008. - № 8. - С. 20-23.

37. Иванов С.А., Растегаев А.В., Галкин В.И. Анализ результатов применения ГРП (на примере Повховского месторождения нефти) // Нефтепромысловое дело. - 2010. - № 7. - С. 54-58.

38. Кривощеков С.Н., Галкин В.И., Волкова А.С. Разработка вероятностно-статистической методики прогноза нефтегазоносности структур // Нефтепромысловое дело. - 2010. - № 7. - С. 28-31.

39. Houze O., Viturat D., Fjaere O.S. Dinamie data analysis. - Paris: Kappa Engineering, 2008. $694 \mathrm{p}$.

40. Van Golf-Racht T.D. Fundamentals of fractured reservoir engineering / Elsevier scientific publishing company. - Amsterdam - Oxford - New York, 1982. $709 \mathrm{p}$.

41. Horne R.N. Modern well test analysis: A computer Aided Approach. $-2^{\text {nd }}$ ed. - Palo Alto: PetrowayInc, 2006. -257 p.

42. Johnson N.L., Leone F.C. Statistics and experimental design. - New York - London - Sydney Toronto, 1977. $-606 \mathrm{p}$.

43. Montgomery D.C., Peck E.A., Introduction to liner regression analysis. - New York: John Wiley \& Sons, 1982. $-504 \mathrm{p}$.

44. Darling T. Well logging and formation evalution. GardnersBooks, 2010. - 336 p.

45. Watson G.S. Statistic on spheres. - New York: John Wiley and Sons, Inc., 1983. - 238 p.

46. Yarus J.M. Stochastic modeling and geostatistics // AAPG. - Tulsa, Oklahoma, 1994. - 231 p.

Please cite this article in English as:

Galkin V.I., Koshkin K.A., Melkishev O.A. The justification of zonal oil and gas potential of the territory of Visimskaya monocline by geochemical criteria. Perm Journal of Petroleum and Mining Engineering, 2018, vol.18, no.1, pp.4-15. DOI: 10.15593/2224-9923/2018.3.1

Просьба ссылаться на эту статью в русскоязычных источниках следующим образом:

Галкин В.И., Кошкин К.А., Мелкишев О.А. Обоснование зональной нефтегазоносности территории Висимской моноклинали по геохимическим критериям // Вестник Пермского национального исследовательского политехнического университета. Геология. Нефтегазовое и горное дело. - 2018. - Т.18, №1. - С.4-15. DOI: 10.15593/2224-9923/2018.3.1 